\title{
Performance test of vacuum frying machine technology in mango skin chips frying process
}

\author{
Nely Ana Mufarida ${ }^{*}$, Asroful Abidin ${ }^{2}$ \\ 1,2Prodi Teknik Mesin, Fakultas Teknik, Universitas Muhammadiyah Jember \\ Jl. Karimata No.49 Jember, Jawa Timur, Indonesia \\ *Corresponding author: nelyana@unmuhjember.ac.id
}

\begin{abstract}
Nowadays, the business of processing fruit flesh into various snacks has been done a lot, but still, a few are starting to look at the use of fruit skins. If usually people are only interested in the use of fruit flesh, creative people will start to be interested in utilizing the fruit skin waste that people usually throw away. One of them is the use of mango peels into fruit chips. By frying and varying the taste of the mango peel, it can create a snack that is different from the others. So that it attracts consumers to consume this snack. The processing of fruit into chips needs technological support so that the quality of the chips produced is acceptable to consumers. One of the ways to produce healthy food without changing its original form is to use vacuum frying technology. Compared to conventional frying, the vacuum system produces a much better product in terms of appearance, color, aroma, and taste. Based on the above, this study discusses the performance test of vacuum frying technology in the utilization of abundant mango peel waste into products that have selling value. height and longer shelf life by making the mango peel into chips so that the economic value of the fruit can be increased. In this study, researchers used direct observation for data collection techniques from the results of research, namely a technique or data collection method by making direct observations on the Vacuum Frying Machine which was tested by recording the results of the observations. The research was conducted in 2 stages, namely preliminary research and main research. Preliminary research was conducted to determine the optimal temperature and frying time range for the mango peel chips used in the frying process. The observations made in the preliminary study were subjective observations of the color and crunch of the mango skin chips. The best results from the preliminary research are used in the main study. Determination of the best frying temperature and time from the results of the organoleptic test by weighing test. In the organoleptic test, the panelists were asked for their opinion regarding the level of their preference for mango skin chip products. The organoleptic test in this study used 15 panelists with the preference test covering 4 quality parameters, namely aroma, taste, crispness, and color.
\end{abstract}

Keywords: Performance Test, Vacuum Frying Machine, Mango Skin Chips

\section{Introduction}

As is well known, there are many benefits of fruit for the human body, one of the fruits that are quite famous among us is the mango. There are so many ingredients and benefits of tropical fruit that is widely grown in Indonesia, namely the mango. Apart from the sweet and delicious mango flesh and the nutritional content in it, it turns out that the mango peel is no less nutritious. Many people who do not consume mango peels only eat the pulp, then throw away the rind. By utilizing the mango peel waste, it can generate business opportunities for you to produce healthy and beneficial snacks [1].

Nowadays, the business of processing fruit flesh into various snacks has been done a lot, but still, a few are starting to look at the use of fruit skins. If usually people are only interested in the use of fruit flesh, creative people will start to be interested in utilizing the fruit skin waste that people usually throw away. One of 
them is the use of mango peels into fruit chips.

The supply of mangoes is always there in any season and never runs out. Adequate raw materials can guarantee the sustainability of the mango skin chips business.

Utilizing mango peel into chips is a business that is rarely glimpsed by people because of the nature of mango peel which is rarely consumed by people, which people usually throw away. Many consumers are attracted to creating new things, so there is no possibility that consumers will be attracted to this product because it is still relatively rare. Therefore, if this business is seriously cultivated, it will certainly be a market opportunity that consumers will be interested in.

The use of mango rind into chips not only creates new creations or innovations in the food sector but can also provide income/income from these creations. By utilizing fruit skin waste, can be a business opportunity.

By frying and varying the taste of the mango peel, it can create a snack that is different from the others. So that it attracts consumers to consume this snack.

The processing of fruit into chips needs technological support so that the quality of the chips produced is acceptable to consumers. One of the ways to produce healthy food without changing its original form is to use vacuum frying technology.

Compared to conventional frying, the vacuum system produces a product that is much better in terms of color appearance, aroma, and taste [2].

Based on the foregoing, this study discusses the performance test of vacuum frying technology in the utilization of abundant mango peel waste into products that have a high selling value and a longer shelf life by making the mango peel into chips so that the economic value of the fruit can increase.

From the background above, the formulation of the problem in this study is to determine what temperature and frying time is right for processing mango peel chips so that the resulting product meets the Chips, Quality Standard.

This study aims to test the performance of a Vacuum Frying frying machine for processing mango peel chips so that heat damage can be avoided in the color, aroma, taste, and nutrition of the product. Besides, oil damage and other consequences caused by high temperatures can be minimized because the process is carried out at low temperature and pressure [3].

One of the products processed by mango peel waste that can be developed and has a good market is chips. Chips are more resistant to storage because they have low water content and no longer physiological processes occur. A vacuum frying machine that has been designed can be used so that mango peel waste can be used as a product that has a high selling value and a longer shelf life by making it into chips [4].

\section{Literature Review}

\section{Benefits of mango skin}

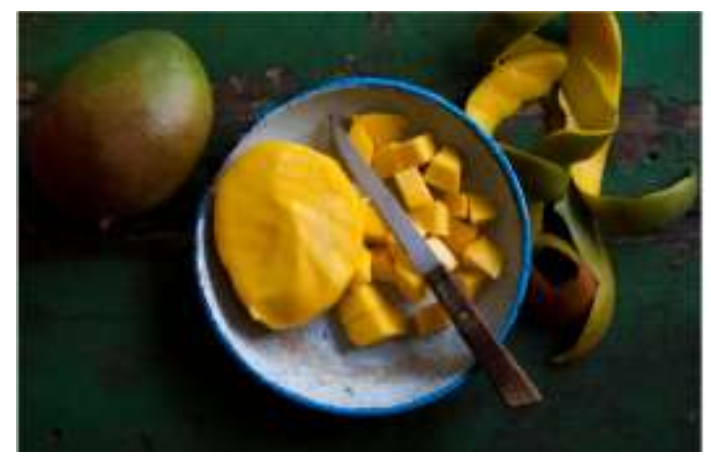

Figure 1. Mango skin

Mangoes are not only delicious but also contain many important nutrients. Uniquely, mangoes not only contain nutrients in the flesh but also in the skin. The benefits of mango peels include [5]:

o Research points to the fact that mango peels are rich in polyphenols, carotenoids, fiber, vitamin $\mathrm{C}$, and various other beneficial compounds. In other studies it is said that eating foods high in vitamin $\mathrm{C}$, polyphenols and carotenoids have a lower risk of heart 
disease, certain types of cancer, and decreased cognitive function of the brain.

- Besides, it was found that mango peel extract has stronger antioxidant and anticancer properties than mango pulp extract.

o Mango rind is also rich in triterpenes [6] and triterpenoids, which are compounds that are useful as anticancer and antidiabetic.

- Mango skin is also rich in fiber, even greater than that contained in the pulp. Fiber is one of the important nutrients that are good for digestive health and can provide a longer feeling of fullness.

- The mango peel contains flavonoids that have antihypertensive properties and reduce the risk of cardiovascular disease [7].

\section{Vacuum frying machine}

Vacuum Frying is a machine that functions to produce fruit or vegetable chips by doing vacuum frying without changing the taste of the fruit. Vacuum Frying can produce various types of fruit chips, such as jackfruit chips, apple chips, zalacca chips, banana chips, pineapple chips, melon chips, zalacca chips, papaya chips, and others [8]. Vacuum Frying can also be used to make vegetable chips and fish chips.

\section{Vacuum frying mechanism}

The following is an explanation of the working mechanism of the Vacuum Frying machine which includes:

a. The ingredients that are put into the frying pan will be vacuum fried. This vacuum frying will make the moisture content in the fruit will be removed and replaced by oil. With the frying temperature used in the range $50{ }^{\circ} \mathrm{C}$ $70^{\circ} \mathrm{C}$ and a pressure of $76 \mathrm{cmHg}$, with frying time between 40 minutes to 60 minutes. Frying with a vacuum frying machine can lower the boiling point below $90^{\circ} \mathrm{C}$, so the chips do not burn [9]. b. For frying, about 12 liters of cooking oil is needed. With a decrease in the boiling point below $90 \mathrm{oC}$ in the frying pan, the structure of the cooking oil content is not easily damaged, so that cooking oil can be used to fry chips up to 100 times in frying. Thus it can save the use of cooking oil [10]. For best results, you should use branded and clear cooking oil, because low-quality cooking oil will affect the color and aroma of the fruit chips. Fruit made with a vacuum frying machine can last for up to half a year, and this also depends on the quality of the packaging.

\section{Research Methods}

\section{Materials and tools}

A. Research materials

The ingredients needed to make mango peel chips are as follows:

1. Mango skin

The raw material for making mango skin chips is mango peel waste.

2. Clean Water

The water in the making of mango peel chips is used to wash the mango peel. The water used must meet the requirements of drinking water and clean water according to the standard Permenkes RI No. 416 / MENKES / PERK / IX / 90. The water is colorless, tasteless, odorless, and contains no harmful substances.

3. Cooking oil

The cooking oil used is coconut oil or palm oil with good quality according to SNI 01 - 3741 - 2002. The use of lowquality cooking oil will produce chips that are not durable.

4. Sodium Solution $\left(\mathrm{Na}_{2} \mathrm{SO}_{3}\right)$

A $0.3 \%-0.5 \%$ sodium bisulfite solution is used to soak the mango peel so that it does not turn brown. In the countryside, this solution can be replaced with pieces of betel leaf. In making mango skin chips, food additives (BTP) can be added. The purpose of adding this food additive is 
to improve the texture, taste, and appearance. The use of these materials both in type and quantity must meet the recommended requirements.

The requirements for food additives refer to SNI 01 0222-1995.

The ingredients added in the manufacture of mango skin chips are:

1. Sugar

The function of sugar in making mango skin chips is to provide a sweet taste. Sugar is made of syrup beforehand with a ratio of $1 \mathrm{~kg}$ of granulated sugar dissolved in 5 cups of water. The sugar used must be of good quality, that is, dry, not smell musty or sour, does not appear to have pulp, and is white. Standard white crystal sugar (SNI 013140-2001).

2. Kitchen salt

The function of table salt is to give a salty taste. The salt used is iodized (SNI 01 - 3556 - 2000).

B. Tools

The equipment needed to make mango peel chips includes basins, cotton pads, stainless steel knives, plastic buckets, vacuum fryers, sealers, gas stoves, containers, plastic containers, $\begin{array}{llll}\text { polypropylene } & (\mathrm{PP}) & 0.8 & \mathrm{~mm}\end{array}$ thick/aluminum foil, and labels.

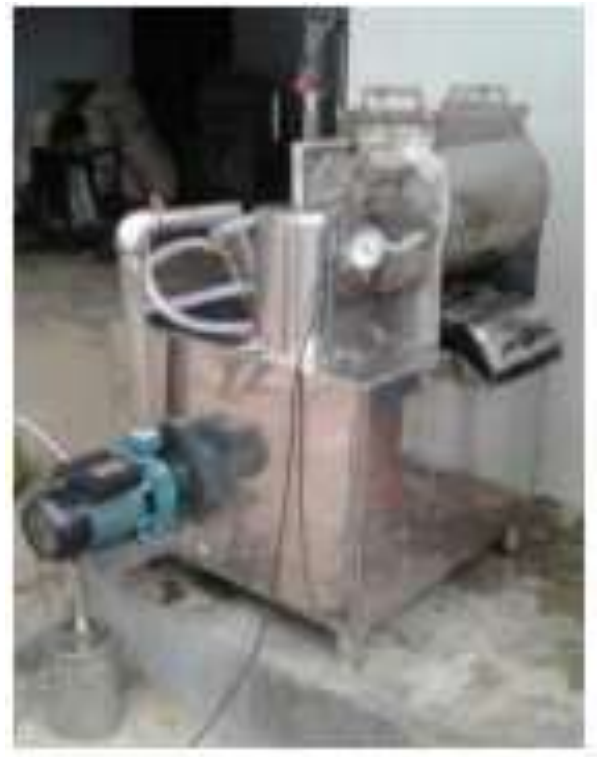

Figure 2. Vacuum frying machine with a capacity of $2 \mathrm{~kg}$ of material
Table 1. Specifications of the Vacuum Frying Machine

\begin{tabular}{|c|c|}
\hline Machine Dimensions & $\begin{array}{l}9800 \mathrm{~mm} \times 710 \mathrm{~mm} \times \\
1150 \mathrm{~mm}\end{array}$ \\
\hline Material & $\begin{array}{l}\text { Food Grade Stainless } \\
\text { Steel Standard }\end{array}$ \\
\hline $\begin{array}{l}\text { Thick Frying Tube } \\
\text { Material }\end{array}$ & $2 \mathrm{~mm}$ \\
\hline Cook Time & $50-70$ minute \\
\hline $\begin{array}{l}\text { Temperature Control } \\
\text { Features }\end{array}$ & $\begin{array}{l}\text { Automatic Thermostat } \\
\text { Control }\end{array}$ \\
\hline Heating & $\begin{array}{l}\text { LPG Gas Stove (Furnace) } \\
\text { Rinnai R1 - 511E }\end{array}$ \\
\hline Fuel & $\begin{array}{l}\text { LPG ( Liquid Petroleum } \\
\text { Gas) }\end{array}$ \\
\hline Oil Capacity & 12 Liter \\
\hline Cooling System & Water Circulation \\
\hline $\begin{array}{l}\text { Cooling Water } \\
\text { Capacity }\end{array}$ & \pm 250 Liter \\
\hline Power & 220 Volt 400 Watt \\
\hline System & $\begin{array}{l}\text { Vacuum Frying (Frying } \\
\text { With Vacuum Frying) }\end{array}$ \\
\hline Vacuum Drive & 2 Inch \\
\hline
\end{tabular}

This research activity was carried out by testing the Vacuum Frying machine using sliced mango peels and then fried and sliced. This experiment was carried out 3 times. The results of the experiment were tested based on the quality standard of mango peel chips. The observational data obtained were analyzed descriptively.

The structural design of the vacuum frying machine

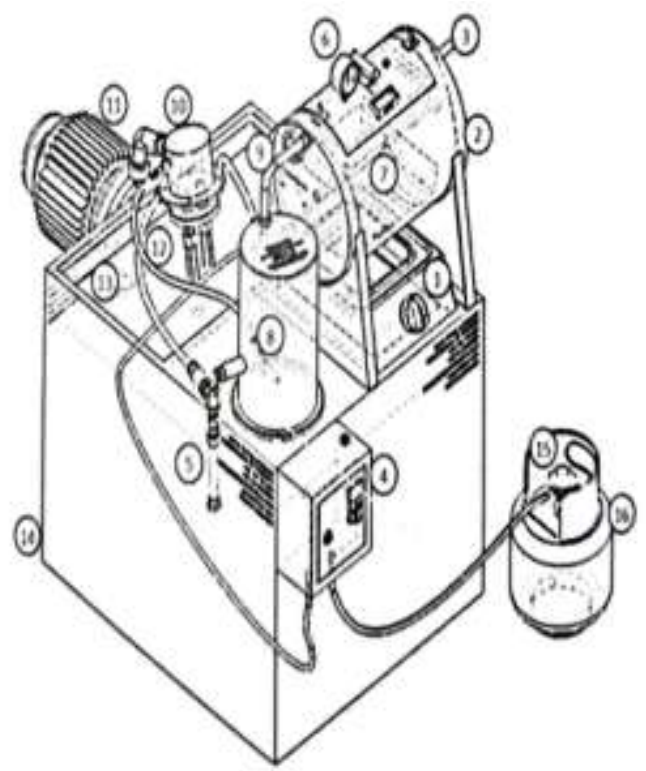

Figure 3. Structural design of the vacuum frying machine 
Caption

(1) heat source,

(2) frying tube,

(3) mixing lever,

(4) temperature control panel,

(5) condensate reservoir,

(6) vacuum gauge,

(7) material collection baskets,

(8) condenser,

(9) water vapor inlet,

(10) water-jet,

(11) circular/centrifugal pump,

(12) cooling channel,

(13) water circulation tub,

(14) framework,

(15) LPG regulator,

(16) LPG gas cylinder.

\section{Flow chart of the process of making manga skin chips}

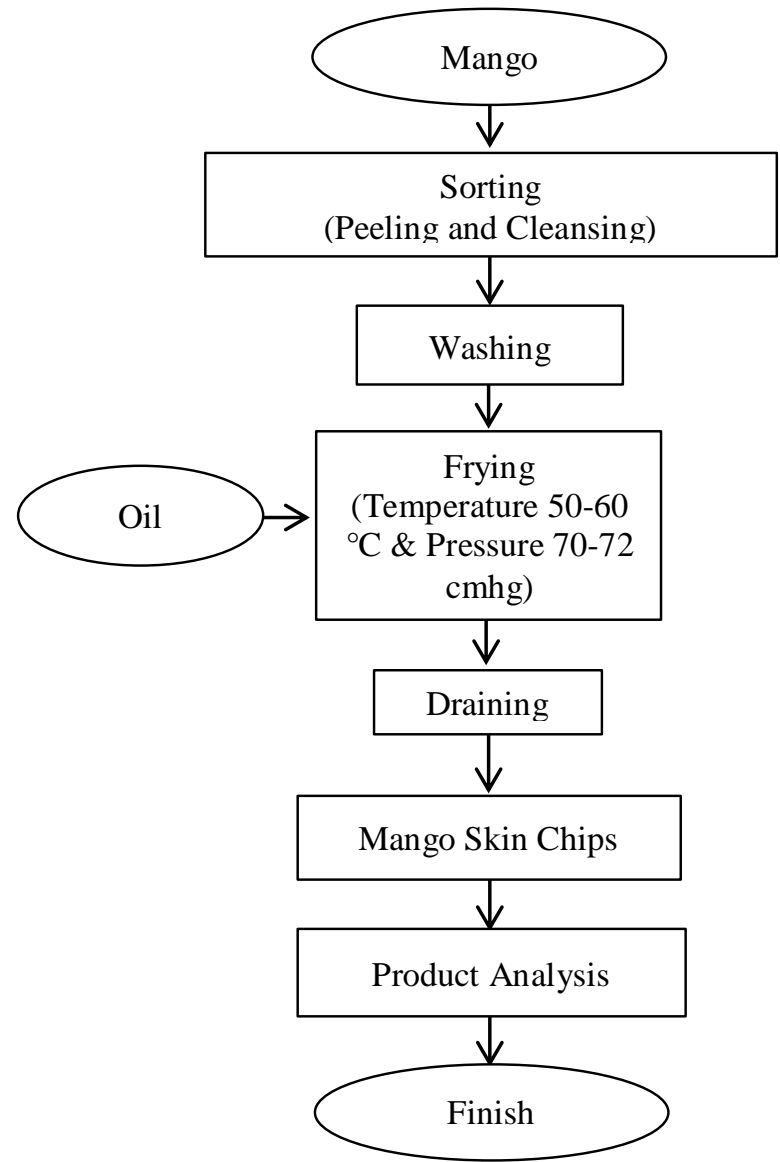

Figure 4. Flow chart of the mango peel chips manufacturing process

\section{Main research design} follows:
1. The independent variable is the variable that is free to be taken, which has been determined by the researcher. The variables are frying temperature and time.

2. The dependent variable (not free) is a variable whose value depends on the predetermined independent variable. In this case the dependent variable is the quality of the mango peel chips.

The study design consisted of three treatments with two replications. The study used 2 factors, namely temperature and frying time with three replications. The temperature factor has 3 levels, namely 50 , 60 , and $65^{\circ} \mathrm{C}$. The time factor also has 3 levels, namely 50, 60, and 70 minutes.

\section{Research stage}

The research carried out consisted of preliminary research and main research. The preliminary research aims to determine the optimal frying temperature and time ranges used in the frying process. The best results from the preliminary research are used in the main study.

The research was conducted in 2 stages, namely preliminary research and main research. Preliminary research was conducted to determine the temperature and time range for frying mango peel chips. The observations made in the preliminary study were subjective observations of the color and crunch of the mango skin chips. Experiments in this preliminary research will be carried out on a trial and error basis. In the preliminary research, empty frying was carried out at a temperature of $55 \mathrm{oC}$ to $65 \mathrm{oC}$ and frying time of 50 minutes to 70 minutes with an input capacity of $2 \mathrm{~kg}$ per process. This treatment was further developed at several stages in the main study. In the main study, the results of preliminary research are further developed at various frying time levels. So that the best temperature and frying time are obtained from this preliminary research subjectively.

\section{Data collection techniques}

In this study, researchers used direct observation for data collection techniques 
from the results of research, namely a technique or data collection method by making direct observations on the Vacuum Frying Machine which was tested by recording the results of the observations.

Determination of the best frying temperature and time from the results of the organoleptic test by weighing test. In the organoleptic test, the panelists were asked for their opinion regarding the level of their preference for mango skin chip products. The organoleptic test in this study used 15 panelists with the preference test covering 4 quality parameters, namely aroma, taste, crispness, and color.

This research was conducted to determine the effect of frying temperature and time on quality and organoleptic parameters and to determine the optimal frying temperature and time seen from the weighting test.

The organoleptic test used is the hedonic test (preference), which involves the assessment of several panelists on the properties of the product. In this test, the panelists were asked for their responses regarding their likes or dislikes. This test uses a score with seven favorite scales, namely 7 (really like), 6 (like), 5 (rather like), 4 (neutral), 3 (somewhat disliked), 2 (disliked), and 1 (very disliked). ). The parameters tested organoleptically from the mango peel chips were a taste, crunchiness, aroma, and color.

\section{Results and Discussion}

The following is a table of data and graphs of organoleptic tests on mango skin chips, including:
a. Organoleptic data on the taste of mango peel chips
b. Organoleptic data on the crispiness of mango peel chips
c. Organoleptic data on the aroma of mango peel chips
d. Organoleptic data on the color of mango skin chips
e. The test results of the importance level of manga skin chips
f. Table Captions

$\mathrm{A}=$ Drying temperature $\left({ }^{\circ} \mathrm{C}\right)$

$\mathrm{A} 1=$ Temperature $55^{\circ} \mathrm{C}$

$\mathrm{A} 2=$ Temperature $60^{\circ} \mathrm{C}$

$\mathrm{A} 3=$ Temperature $65^{\circ} \mathrm{C}$

$\mathrm{B}=$ Drying Time (minutes)

$\mathrm{B} 1=$ Time 50 minutes

$\mathrm{B} 2=$ Time 60 minutes

$\mathrm{B} 3=$ Time 70 minutes

Table 2. Organoleptic data on mango skin chips flavor

\begin{tabular}{|c|c|c|c|c|c|c|c|c|c|}
\hline \multirow{4}{*}{ 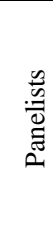 } & \multicolumn{3}{|c|}{$55^{\circ} \mathrm{C}$} & \multicolumn{3}{|c|}{$60^{\circ} \mathrm{C}$} & \multicolumn{3}{|c|}{$65^{\circ} \mathrm{C}$} \\
\hline & 욜ㄹㄹㄹ & ᄋ & $\stackrel{\stackrel{\mathscr{d}}{\Xi}}{.}$ & ○ & ○ & $\stackrel{\stackrel{\Xi}{\Xi}}{\stackrel{\Xi}{\Xi}}$ & 유 $\stackrel{\stackrel{\mathscr{E}}{\Xi}}{\stackrel{\Xi}{\Xi}}$ & ○ & $\stackrel{\stackrel{\mathscr{U}}{\Xi}}{\stackrel{\Xi}{\Xi}}$ \\
\hline & A1 & A1 & A1 & A2 & A2 & A2 & A3 & A3 & A3 \\
\hline & B1 & B2 & B3 & B1 & B2 & B3 & B1 & B2 & B3 \\
\hline 1 & 4 & 6 & 4 & 4 & 6 & 3 & 3 & 4 & 5 \\
\hline 2 & 5 & 7 & 5 & 6 & 5 & 6 & 4 & 3 & 7 \\
\hline 3 & 3 & 5 & 6 & 4 & 7 & 5 & 5 & 6 & 6 \\
\hline 4 & 4 & 3 & 4 & 5 & 6 & 4 & 6 & 4 & 5 \\
\hline 5 & 5 & 6 & 6 & 6 & 5 & 7 & 4 & 4 & 7 \\
\hline 6 & 2 & 5 & 3 & 5 & 6 & 6 & 6 & 7 & 7 \\
\hline 7 & 3 & 5 & 2 & 4 & 7 & 5 & 5 & 6 & 6 \\
\hline 8 & 3 & 3 & 3 & 3 & 4 & 5 & 3 & 5 & 5 \\
\hline 9 & 4 & 5 & 4 & 5 & 5 & 3 & 5 & 7 & 6 \\
\hline 10 & 4 & 6 & 5 & 3 & 4 & 5 & 6 & 5 & 5 \\
\hline 11 & 3 & 5 & 3 & 6 & 5 & 4 & 4 & 4 & 5 \\
\hline 12 & 2 & 4 & 4 & 4 & 5 & 7 & 4 & 4 & 6 \\
\hline 13 & 5 & 5 & 5 & 5 & 4 & 6 & 6 & 7 & 5 \\
\hline 14 & 6 & 5 & 4 & 5 & 7 & 5 & 5 & 6 & 6 \\
\hline 15 & 5 & 7 & 6 & 6 & 6 & 4 & 5 & 5 & 7 \\
\hline స్త్ర & 58 & 77 & 64 & 71 & 82 & 75 & 71 & 77 & 88 \\
\hline
\end{tabular}

:

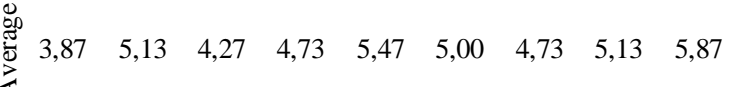

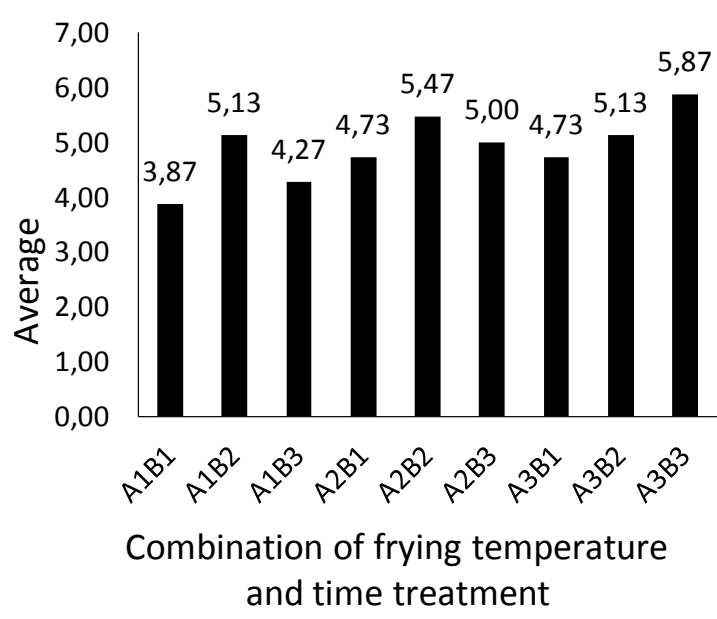

Figure 5. Graphic organoleptic data on mango skin chips flavor 
Table 3. Organoleptic data on mango skin crunchiness

\begin{tabular}{|c|c|c|c|c|c|c|c|c|c|}
\hline \multirow{4}{*}{$\frac{\tilde{0}}{\stackrel{0}{0}}$} & \multicolumn{3}{|c|}{$55^{\circ} \mathrm{C}$} & \multicolumn{3}{|c|}{$60^{\circ} \mathrm{C}$} & \multicolumn{3}{|c|}{$65^{\circ} \mathrm{C}$} \\
\hline & $\circ \stackrel{\stackrel{\mathscr{\Xi}}{\Xi}}{\circ}$ & 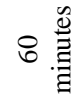 & 율 & $\circ \stackrel{\stackrel{\mathscr{\Xi}}{\Xi}}{\circ} \cdot \stackrel{\Xi}{\Xi}$ & ○욜 & $\circ \stackrel{\stackrel{\mathscr{Z}}{\Xi}}{\stackrel{\Xi}{\Xi}}$ & ○ & ○욜 & $\curvearrowright \stackrel{\stackrel{\mathscr{U}}{\Xi}}{\stackrel{\Xi}{\Xi}}$ \\
\hline & $\overline{\mathrm{A} 1}$ & $\overline{\mathrm{A} 1}$ & A1 & A2 & A2 & A2 & A3 & $\overline{\mathrm{A} 3}$ & A3 \\
\hline & B1 & B2 & B3 & B1 & B2 & B3 & B1 & B2 & B3 \\
\hline 1 & 4 & 5 & 6 & 6 & 5 & 6 & 5 & 5 & 7 \\
\hline 2 & 3 & 3 & 4 & 4 & 6 & 7 & 5 & 6 & 6 \\
\hline 3 & 5 & 6 & 6 & 5 & 6 & 5 & 6 & 5 & 6 \\
\hline 4 & 5 & 4 & 5 & 4 & 5 & 7 & 5 & 6 & 7 \\
\hline 5 & 5 & 5 & 4 & 5 & 7 & 7 & 4 & 7 & 6 \\
\hline 6 & 4 & 4 & 5 & 4 & 7 & 6 & 5 & 6 & 7 \\
\hline 7 & 3 & 4 & 5 & 3 & 4 & 5 & 4 & 7 & 6 \\
\hline 8 & 2 & 3 & 4 & 5 & 6 & 6 & 3 & 7 & 5 \\
\hline 9 & 5 & 4 & 6 & 4 & 6 & 6 & 3 & 6 & 5 \\
\hline 10 & 4 & 5 & 7 & 5 & 7 & 6 & 4 & 5 & 7 \\
\hline 11 & 3 & 3 & 5 & 5 & 7 & 5 & 5 & 6 & 6 \\
\hline 12 & 5 & 6 & 7 & 6 & 5 & 6 & 6 & 5 & 7 \\
\hline 13 & 5 & 5 & 7 & 3 & 4 & 6 & 4 & 5 & 6 \\
\hline 14 & 3 & 3 & 5 & 4 & 5 & 7 & 5 & 6 & 5 \\
\hline 15 & 4 & 5 & 5 & 5 & 5 & 5 & 6 & 7 & 6 \\
\hline 吾 & 60 & 65 & 81 & 68 & 85 & 90 & 70 & 89 & 92 \\
\hline 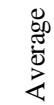 & 4,00 & 4,33 & 5,40 & 4,53 & 5,67 & 6,00 & 4,67 & 5,93 & 6,13 \\
\hline
\end{tabular}

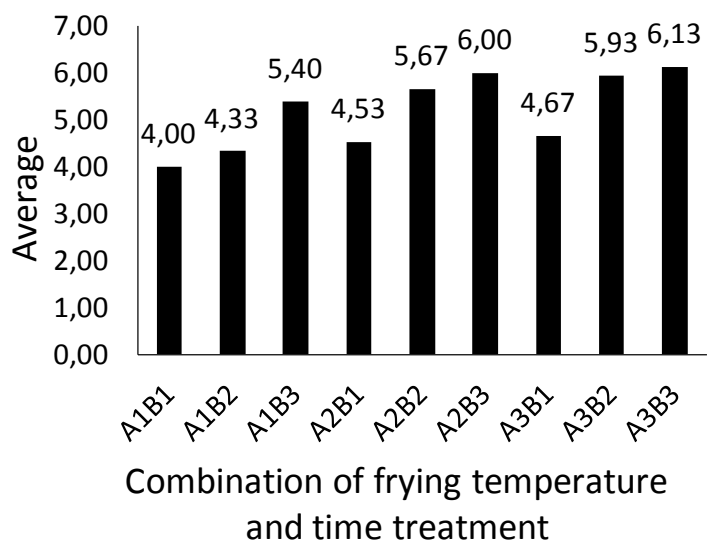

Figure 6. Graphic organoleptic data on mango skin crunchiness

Table 4. Organoleptic data on the aroma of mango skin chips

\begin{tabular}{|c|c|c|c|c|c|c|c|c|c|}
\hline \multirow{4}{*}{ 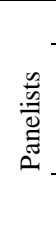 } & \multicolumn{3}{|c|}{$55^{\circ} \mathrm{C}$} & \multicolumn{3}{|c|}{$60^{\circ} \mathrm{C}$} & \multicolumn{3}{|c|}{$65^{\circ} \mathrm{C}$} \\
\hline & 요롤 & 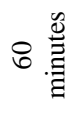 & $\stackrel{\stackrel{\mathscr{\Xi}}{\Xi}}{\stackrel{\Xi}{\Xi}}$ & 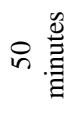 & 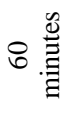 & $\stackrel{\stackrel{\mathscr{Q}}{\Xi}}{\stackrel{\Xi}{\Xi}}$ & 욜ㄹㄹ & 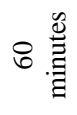 & 요 $\stackrel{\stackrel{\mathscr{\Xi}}{\Xi}}{\Xi}$ \\
\hline & A1 & A1 & A1 & A2 & A2 & A2 & A3 & A3 & A3 \\
\hline & B1 & B2 & B3 & B1 & B2 & B3 & B1 & B2 & B3 \\
\hline 1 & 3 & 5 & 5 & 6 & 5 & 7 & 5 & 6 & 6 \\
\hline 2 & 4 & 4 & 7 & 5 & 5 & 5 & 5 & 5 & 6 \\
\hline 3 & 4 & 5 & 6 & 4 & 6 & 6 & 4 & 5 & 7 \\
\hline 4 & 5 & 4 & 6 & 3 & 5 & 6 & 4 & 4 & 7 \\
\hline 5 & 5 & 6 & 7 & 4 & 5 & 7 & 6 & 6 & 6 \\
\hline 6 & 4 & 5 & 6 & 6 & 6 & 6 & 3 & 6 & 7 \\
\hline 7 & 4 & 6 & 7 & 5 & 6 & 5 & 4 & 5 & 5 \\
\hline
\end{tabular}

\begin{tabular}{cccccccccc}
\hline 8 & 3 & 5 & 6 & 4 & 7 & 6 & 5 & 7 & 6 \\
\hline 9 & 5 & 5 & 5 & 6 & 5 & 7 & 4 & 5 & 6 \\
\hline 10 & 4 & 6 & 6 & 5 & 6 & 7 & 6 & 6 & 5 \\
\hline 11 & 5 & 5 & 5 & 5 & 6 & 5 & 5 & 5 & 7 \\
\hline 12 & 4 & 5 & 5 & 4 & 4 & 6 & 5 & 5 & 6 \\
\hline 13 & 3 & 4 & 6 & 6 & 5 & 7 & 6 & 7 & 6 \\
\hline 14 & 2 & 5 & 7 & 5 & 6 & 6 & 5 & 6 & 5 \\
\hline 15 & 2 & 5 & 5 & 4 & 6 & 5 & 5 & 5 & 5 \\
\hline ॠँّ & 57 & 75 & 89 & 72 & 83 & 91 & 72 & 83 & 90 \\
\hline
\end{tabular}

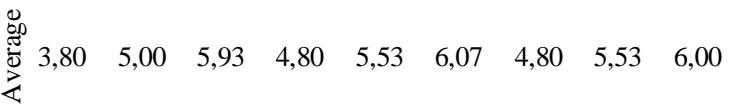

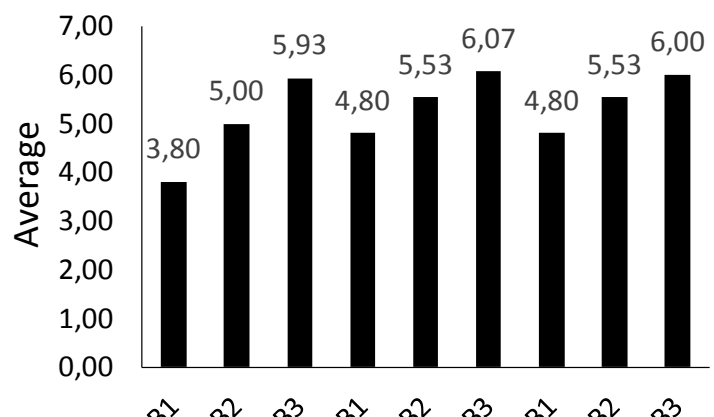

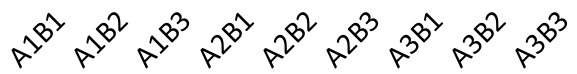

Combination of frying temperature and time treatment

Figure 7. Graphic organoleptic data on the aroma of mango skin chips

Table 5. Organoleptic data on color of mango skin chips

\begin{tabular}{|c|c|c|c|c|c|c|c|c|c|}
\hline \multirow{4}{*}{ 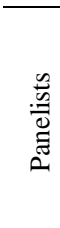 } & \multicolumn{3}{|c|}{$55^{\circ} \mathrm{C}$} & \multicolumn{3}{|c|}{$60^{\circ} \mathrm{C}$} & \multicolumn{3}{|c|}{$65^{\circ} \mathrm{C}$} \\
\hline & 诲产 & 8 曽 & $尺$ 惫 & 况泀 & 8 蒫 & $尺$ 恶 & 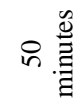 & 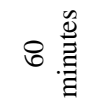 & $尺$ 曽 \\
\hline & $\mathrm{A} 1$ & $\mathrm{~A} 1$ & $\mathrm{~A} 1$ & $\mathrm{~A} 2$ & $\overline{\mathrm{A} 2}$ & $\mathrm{~A} 2$ & $\mathrm{~A} 3$ & A3 & $\overline{\mathrm{A} 3}$ \\
\hline & B1 & B2 & B3 & B1 & B2 & B3 & B1 & B2 & B3 \\
\hline 1 & 3 & 5 & 7 & 4 & 6 & 4 & 6 & 7 & 5 \\
\hline 2 & 3 & 6 & 5 & 3 & 5 & 6 & 5 & 6 & 4 \\
\hline 3 & 5 & 7 & 6 & 3 & 7 & 6 & 6 & 5 & 4 \\
\hline 4 & 4 & 4 & 6 & 4 & 5 & 5 & 5 & 6 & 3 \\
\hline 5 & 3 & 6 & 5 & 5 & 6 & 7 & 4 & 6 & 7 \\
\hline 6 & 4 & 6 & 5 & 5 & 5 & 6 & 6 & 7 & 5 \\
\hline 7 & 3 & 5 & 7 & 4 & 5 & 5 & 3 & 6 & 7 \\
\hline 8 & 3 & 4 & 6 & 5 & 7 & 6 & 4 & 5 & 6 \\
\hline 9 & 4 & 5 & 6 & 5 & 6 & 7 & 3 & 6 & 6 \\
\hline 10 & 5 & 5 & 6 & 4 & 6 & 6 & 4 & 6 & 5 \\
\hline 11 & 6 & 6 & 5 & 4 & 7 & 5 & 5 & 7 & 5 \\
\hline 12 & 4 & 5 & 7 & 5 & 6 & 6 & 4 & 6 & 4 \\
\hline 13 & 6 & 5 & 6 & 3 & 5 & 4 & 3 & 5 & 6 \\
\hline 14 & 5 & 4 & 5 & 4 & 6 & 4 & 4 & 6 & 5 \\
\hline 15 & 6 & 4 & 4 & 4 & 5 & 5 & 4 & 6 & 5 \\
\hline 胥 & 64 & 77 & 86 & 62 & 87 & 82 & 66 & 90 & 77 \\
\hline 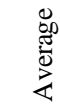 & 27 & 5,13 & 5,73 & 4,13 & 5,80 & 5,47 & 4,40 & 6,00 & 5,13 \\
\hline
\end{tabular}




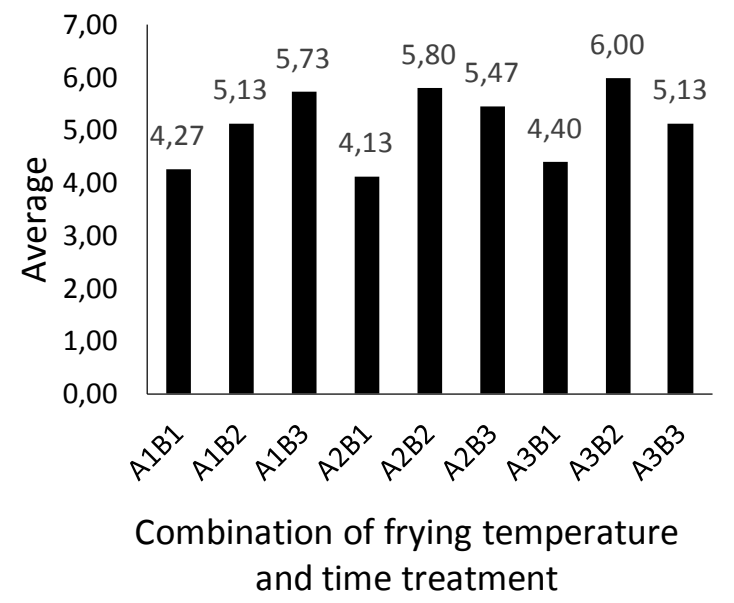

Figure 7. Graphic organoleptic data on color of mango skin chips

Table 6. Test results of mango skin chips importance level

\begin{tabular}{ccccc}
\hline Panelists & Taste & Crunchy & Aroma & Color \\
\hline 1 & 4 & 3 & 2 & 1 \\
\hline 2 & 4 & 3 & 3 & 3 \\
\hline 3 & 3 & 4 & 4 & 2 \\
\hline 4 & 3 & 4 & 3 & 2 \\
\hline 5 & 4 & 3 & 2 & 3 \\
\hline 6 & 4 & 3 & 3 & 3 \\
\hline 7 & 3 & 4 & 4 & 2 \\
\hline 8 & 3 & 3 & 2 & 3 \\
\hline 9 & 4 & 4 & 3 & 2 \\
\hline 10 & 3 & 3 & 1 & 2 \\
\hline 11 & 4 & 3 & 2 & 3 \\
\hline 12 & 3 & 2 & 3 & 2 \\
\hline 13 & 3 & 2 & 4 & 2 \\
\hline 14 & 3 & 4 & 4 & 1 \\
\hline 15 & 4 & 3 & 2 & 2 \\
\hline Total & 52 & 48 & 42 & 33 \\
\hline Average & 3,47 & 3,20 & 2,80 & 2,20 \\
\hline Weight $(\%)$ & 34,7 & 32,00 & 28,00 & 22,00 \\
\hline
\end{tabular}

\section{Conclusion}

The best temperature treatment and frying time for making mango peel chips is a temperature of $65 \mathrm{oC}$ for 50 minutes. The results of the questionnaire showed that the panelists tended to rank taste first $(34.7 \%)$, crunchiness in second (32\%), the aroma in third (28\%), and color in fourth (22\%). Panelists are more inclined to taste values. The best treatment temperature for making mango peel chips is a temperature of $65^{\circ} \mathrm{C}$ and 50 minutes for frying time.

\section{References}

[1] Mukti, GW., Rasmikayati, E., Kusumo, RAB., dan Fatimah, S. 2018. Peningkatan Nilai Tambah Limbah Kulit Mangga Melalui Pelatihan Pembuatan Keripik Dan Manisan Kulit Mangga. Jurnal Bakti Masyarakat Indonesia, Vol. 1, No. 1, 54-60.

[2] Tumbel N, Kaseke, HFG, Manurung S. Performance Test Of Vacuum Frying Machine Applied To Jackfruit. Jurnal Penelitian Teknologi Industri Vol. 7 No. 2 Desember 2015: 129-148 ISSN No. 2085-580X. Balai Riset dan Standardisasi Industri. Manado.

[3] Herlina, Astriyaningsih, E., Windarti, W.S., dan Nurhayati. 2017. Tingkat Kerusakan Minyak Kelapa Selama Penggorengan Vakum Berulang Pada Pembuatan Ripe Banana Chips (RBC). Jurnal Agroteknologi, Vol.11 No. 02 : 186-193.

[4] Rumah Mesin. 2016. Pusat Mesin Usaha Anda. Artikel Proses. Tips Jitu Bisnis Keripik Kulit Buah Mangga Agar Menguntungkan. Yogyakarta.

[5] Andini CW, Upahita D. 2019. Kulit Mangga Ternyata Kaya Manfaat, Tapi Apa Bisa Dimakan?. 2019.

[6] Fakhrudin, N., Putri, P.S., Sutomo, dan Wahyuono, S. 2013. Aktivitas Antiinflamasi Ekstrak Metanolik Buah Mangga Kasturi (Mangifera Casturi) Melalui Penghambatan Migrasi Leukosit Pada Mencit Yang Diinduksi Thioglikolat. Trad. Med. J., Vol. 18 No.3 : 151-156.

[7] Katike Umamahesh, S. N. (2016). Evaluation of antioxidant activity, total phenolics and total flavonoids in peels of five cultivars of mango (Mangifera indica) fruit. Medicinal Plants Studies 2016.

[8] Jamaludin P. 2018. Pengolahan Aneka Kerupuk dan Keripik Bahan Pangan. Makassar: Badan Penerbit Universitas Negeri Makassar.

[9] Afrozi, S., Mufarida, N.A., dan Sofiyah, R. 2018. Hubungan Optimalisasi Suhu Dan Waktu 
Penggorengan Pada Mesin Vacuum Frying Terhadap Peningkatan Kualitas Keripik Pisang Kepok.

Proteksion, Vol. 2 No. 2: 43-52.

[10] Mufarida, N.A. Pengaruh Optimalisasi Suhu Dan Waktu Pada Mesin Vacuum Frying Terhadap Peningkatan Kualitas Keripik Mangga Situbondo. Jurnal Penelitian Ipteks, Vol. 4 No. 1: 22-33. 